The Reference Librarian, 2004, Vol. 42, No. 87 \& 88, pp.163-178.

DOI: $10.1300 / J 120 v 42 n 87 \_06$

http://www.taylorandfrancis.com/

http://www.informaworld.com/smpp/title content=t792306953 db=all

http://www.informaworld.com/openurl? genre=article \&issn $=0276-3877 \&$ volume $=42 \&$ issue $=87 \&$ spage $=163$

(c) 2004 by The Haworth Press, Inc. All rights reserved.

\title{
Reading African Women's Writing: The Role of Librarians in Expanding the Canon
}

\author{
Miriam Conteh-Morgan
}

Miriam Conteh-Morgan is Assistant Professor, Bibliographer for Linguistics, African Studies and French, Information Services Department, The Ohio State University Libraries, 1858 Neil Avenue Mall, Columbus, $\mathrm{OH}$

SUMMARY. This paper will briefly review the canon debate in African literature, situating it within a wider context of debates on other non-Western, non-central or emerging disciplines. It will then examine ways in which reference services can respond to the challenge of canon expansion, and how librarians can impact the study of African women writers in universities and colleges. I will approach these topics from two perspectives. The first involves reference librarians in their traditional role as information mediators. Using the works of female writers as examples in instruction sessions and reference guides are ways in which traditional methods can be given a new twist. In so doing, reference librarians will be combining intercultural literacy with information literacy. A bibliography of selected works will also be given that will help general reference librarians strengthen their collections and educate themselves on the subject.

The second will be on ways in which librarians can add a layer to traditional mediating by becoming academic activists. In other words, instead of passively waiting for courses to be created and then supporting them, librarians can market to faculty ideas for possible uses of the Africana collection and thus provide impetus for new course development. Suggested initiatives include developing theme-related guides or readers' advisory based on African women's texts, and distributing them to other Area Studies faculty-an obvious way to encourage comparative, interdisciplinary research and teaching. Librarians can also hold workshops to demonstrate how works such as Aidoo's Changes or Dangaremgba's Nervous Conditions that examine the many faces of modern Africa can be discussed in social history, politics or education courses; or Alifa Rifaat's works dealing with women in Islamic communities in a religion or comparative law course. Additionally, libraries need to go beyond in-house, libraryonly lectures to organizing, for example, campus-wide author lecture series.

To effectively implement these initiatives, reference librarians should collaborate more closely with Africana and Area Studies bibliographers. As librarians in the 21st century, we should be more proactive in our academic communities. We can generate impetus for breaking the literary canon and broadening literary research, foster greater understanding of African culture, while still playing our time-honored roles of guide, mediator, culture-keeper, and agents of change.

\section{INTRODUCTION}

Library literature's attention to African Studies in general has focused almost exclusively on collection development and cataloging issues (for example, Malanchuk, 1991; Aderibigbe and Udoh, 1990). The few works that specifically discuss African literature also approach it from the acquisitions and cataloguing angle (Amaeshi, 1985; Wolcke-Renk, 1984). To date, only one article in the electronic database Library Literature deals with African women's writing, and that, too, has a collection development bias (Richey, 1995). Similarly, works suggesting ways in which librarians can expand literary canons tend to approach the topic from a collection development standpoint (Doherty 1998; Krazert and Richey, 1998; Quinn, 1995), and only a few deal specifically with literary reference (Benefiel, Miller and Ramirez, 1997; Adams and 
Benefiel, 2000).

Going beyond collection development, and thinking about reference and outreach services that could help open up the canon is what this article will discuss. Indeed, it has been acknowledged that librarians "can . . . force the canon to evolve and become more inclusive" (Doherty, 1998, p. 405). I will examine, from two perspectives, ways in which reference librarians can help create an enabling environment for the study of African women writers in U.S. universities and colleges, thus helping to expand the African literary canon. The first discusses how reference librarians can use some traditional methods in their role as information mediators to make African women's writing more visible. The other perspective examines ways in which librarians can add a layer to traditional mediating by taking a more proactive approach. In other words, instead of passively waiting for courses to be created and then supporting them, librarians can market to their campus community new approaches and ideas for possible uses of African women writers' works that could serve as an impetus for course development or enhancement. This philosophy is undergirded by the belief that "librarians know that their libraries hold far more useful material than their audiences-or their potential audiencesgenerally recognize" (Cullen, 1988, p. 76). It is hoped that these strategies would stimulate the opening of the literary canons, African and world.

While the suggestions given can be applied to other areas or disciplines, examples and strategies will focus on the use the works of African women writers within the contexts of library outreach, and interdisciplinary and intercultural teaching and research.

\section{BACKGROUND}

The study of Africa was introduced into the curriculum of institutions of higher learning in the United States as a result of parallel and interconnected developments of the 1960s: the Black Consciousness movement in the U.S., the Cold War, and the decolonization movements in Africa which created the need for the systematic study of other regions of the world. One can say that African literature came of age when, two decades later, in 1986, Nigeria's Wole Soyinka won the Nobel Literature Prize, and was quickly followed by Egypt's Naguib Mafouz and South Africa's Nadine Gordimer. However, it is a literature still relatively unknown to many nonAfricans and little explored on many U.S. campuses primarily because the study of African writers has remained largely within Black/Africana Studies programs, and has not made really significant inroads into the central curriculum of many institutions. Arguably, writers like Wole Soyinka, Chinua Achebe, Ngugi wa Thiongo, the "presiding triumvirate" of Anglophone African literature (Lindfors, 1995, p. 59), and the Senegalese (francophone) Leopold Senghor are better known outside of Africana Studies departments as they are read in literature courses in English, Comparative Studies, or French departments, and have more critical works devoted to their writing.

Female writers have not been similarly privileged in curricula or other canon-conferring sources as anthologies. When Lindfors applied the Famous Authors' Reputation Test he devised to examine the frequency with which Anglophone writers were discussed in African literature journals and books published between 1936 and 1986, of the thirty-seven authors identified, six are female; none, however, appears in the first fifteen spots. The same test was applied to two African literature journals, Research in African Literatures and African Literature Today, and to conference presentations of the African Literature Association (ALA) and African Studies Association (ASA) for the period 1975 to 1997, to determine which women writers, Anglophone 
and francophone, were the subject of critical analyses (Conteh-Morgan, 1999). It was revealed that women writers have not had much representation in these venues either: only fifty out of the combined eight hundred conference papers identified were on women writers, and not all of them are African. Another similarity between both studies is that Bessie Head came out on top of the list of women writers.

African women writers do not fare much better in the commonly used research databases, subject searches on specific authors conducted in the MLA International Bibliography (Jan. 29, 2003) show. The authors searched were: Nadine Gordimer, Bessie Head, Mariama Ba, Buchi Emecheta, Tsitsi Dangarembga, Assia Djebar, and Ama Ata Aidoo, all of whom appear on the Lindfors list and/or Africa's 100 Best Books of the 20th century. The top three hits are Gordimer (313), Head (168), and Djebar (121). They are followed, in descending order, by Emecheta, Aidoo, Ba, and Dangarembga. In Literature Online, 51 of the 229 African authors included in the database are female (Jan. 18, 2003).

Ama Ata Aidoo, the 1992 Commonwealth Prize winner for her book Changes, speaks of the collective pain of women writers: "It is especially pathetic to keep on writing without having any consistent, active, critical intelligence that is interested in you as an artist" (Aidoo, 1988). This observation is all the more glaring when one compares the representation of two Nobel Prize winners in the MLA: Gordimer's 313 hits as against Soyinka's 588, despite the fact that the former is considered part of two literary traditions, African and British.

With women's voices seemingly lost amid the "humming and bustling" of their male counterparts (James, 1990), more of their works needs to break through the hegemonic control of the canon-conferring establishment; in short, the African literary canon needs to be opened up. Librarians can be useful in bringing more visibility to African women's writing on their campuses by helping "to raise the threshold of access and affirmation" (Allan, p. 55).

\section{DEFINING THE CANON}

It will be worthwhile to consider at this point some definitions of the term "literary canon" and briefly revisit the canon debate. There are a multitude of definitions, but they all share a few basic characteristics. A literary canon, as defined by those with a "classical" point of view, consists of a body of works recognized for their literary quality, timelessness and universality (Heinzkill, 1990). Gates (1990) defines the canon as works by " 'crucially central' authors [who are] indispensable to an understanding of the shape, and shaping, of the tradition" (p. 102). Implicit in both views is the notion of a common interpretation of what constitutes a canonical work. Indeed, consensus on what literary quality is and the tradition that defines it can only be grounded in the ideals of a community of "experts" and readers; ideals shared basically because of the common heritage or consciousness of the group.

However, these definitions raise a number of questions. The notion of timelessness suggests that hallowed works remain that way forever, and are not open to new interpretations or influences that could "dethrone" them. But it is also known that canons evolve, particularly because "canon formation and the rise and fall of artistic and ideological trends are interrelated" (Szegedy-Maszak, p. 20). The definitions also suggest that a multiplicity of traditions exists, with canons based on these different traditions. As such, this not only undermines the issue of universality, but also raises the other question of whether these multiple canons will independently continue to orbit in their own proscribed spaces (or traditions), or merge at some point. Canon purists would like to believe the former, but Heinzkill (1990), with particular 
reference to English literary studies, thinks that there will be a merging of canons from different cultures that all share a common language tradition, English-put differently, a super canon created out of the plurality of canons of literatures in English. Another school of thought holds the view that multiple canons will recognize each other's status as equal but remain separate. If one subscribes to the former position, then many African writers will become part of the canon of literature in English, French, and Portuguese; otherwise, they will remain a part of their continental or national canons.

\section{NEW CANONS, NEW IMPERATIVES}

\section{Implications for the Faculty}

Whether or not one subscribes to the theory of single or multiple canons, reality points to significant changes in the academic world that have had an impact on the canon debate. The rereading of texts and the application of non-literary theories to literary texts has led to novel interpretations of literary works. For example, there has been a shift toward incorporating perspectives from cultural studies and history to focus on the contexts in which texts are produced and received. Additionally, insights gained from other literary traditions, and readings from the perspective of the "subaltern" have led to fresh examinations of the classics of the western tradition, and ultimately to a questioning of their stranglehold on emerging canons. Theories of post-isms-post-modernism, and postcolonialsm to name two-have also provided liberating approaches to critical analyses. As such, voice and space have been given to the hitherto unheard and unseen.

As has been generally acknowledged, this academic climate has had a salutary effect on, for example, gender studies and area studies. In areas where both these disciplines intersect, for example, "the new trend toward global women's studies has moved Africa to a more central position" (Berger, 1997, p. 10). But more importantly, these changes of direction mean that boundaries of disciplines are no longer fossilized or clearly demarcated, and that faculty need to be reaching out to colleagues in other departments and disciplines. According to David Chioni Moore (2001), "Postcolonial critique has also illuminated parallels between areas heretofore seen as noncomparable, such as Senegal and India, and it has energized fields such as Irish Studies" (p. 112). These centrifugal approaches have had enormous effects on the study of Africa. Berger believes "the prospect of new collaboration across regional and disciplinary boundaries promises to enhance rather than threaten African Studies" (p. 12), for it will bring "both area-based and disciplinary knowledge to bear on particular issues" (p. 5). In short, the "I word" (Ryan, quoted in Searing, 1996), "interdisciplinarity," is what is now driving research, publication, and teaching.

There is indeed a new dawn for African Studies in general, the right climate for the works of African women in particular to receive the wider recognition they deserve. Christopher Miller (1993) has it right when he asserts that there is currently "a positive intellectual atmosphere for the teaching of African literature, an atmosphere conducive to multicultural inquiry and intercultural literacy" (p. 219).

\section{The Role of the Library}

For many teaching faculty, however, there is a gap between wanting to take advantage of 
the favorable atmosphere and actually incorporating new initiatives into the curriculum. Hunter (2000) points to another group of professionals on campuses that can bridge this divide. As it is widely acknowledged, research, especially in the major literary databases, presupposes some knowledge of authors' names, as thematic searches are not always very fruitful. On the need for intercultural and interdisciplinary work, Hunter acknowledges that:

[faculty] are individually and collectively ill equipped by training to do this work. In our own "cultural" investigations, not to mention those we lead or provoke our students to do, we do not know our way around. We are going to be dependent ... on those whose knowledge of the bibliographies, texts, and materials of other disciplines and other subject areas is larger, broader, and especially deeper than ours ... The cries you hear from faculty these days ... will inevitably be directed mostly to [librarians]. (p. 296)

Cries for help and the knowledge that faculty expect librarians to provide research-related answers is not new. But in this brave new world he describes, librarians have an even more pivotal role to play to bring together, in a coherent and cohesive whole, the seemingly discrete strands of the multi-canon, intercultural, and interdisciplinary mosaic. As a result, "A librarian not only must have specialized knowledge of [a] field as a whole but also must be a generalist at ease with sources in a number of more-or-less related fields" (Adams and Benefiel, 2000, p. 258).

Librarians themselves have long been aware of the library's unique position as the site on campus where all of these strands come together, and their leadership role in using resources that facilitate the intercultural and interdisciplinary connections. Having historically responded to and supported the academy's enshrinement of the Great Books, librarians may now need to participate in enlarging the canons. By being actively involved in the curricular reforms on campus and becoming "co-creators of the curriculum" (Pelster and Baker), they can give more visibility to the works in their collections hitherto unfamiliar to the majority, not least, those of African women writers.

\section{TRADITIONAL METHODS AND INNOVATIVE STRATEGIES}

\section{Reference Service}

Although the various activities that are at the heart of librarianship will remain unchanged for the foreseeable future, the way those activities are carried out will evolve to match the new environments in which information is produced, sought, and used. As a result, in the words of Shiri, the mother-narrator in Maraire's Zenzele, "we [librarians] are all bridges," between old needs and new forms of delivery, and between new needs and uses. Or as Ramatoulaye in Mariama Ba's So Long a Letter puts it, we have to necessarily become "messengers of a new design" (p. 25).

In being able to mediate between actual or envisaged information needs on the one hand, and the resources to meet those needs on the other, reference librarians have always sought innovative ways of delivering and adding value to their services. It will be no different when that need or resource happens to be related to African women's writing. Generalists can bring those same skills to bear on subject specialties like African literature and their patrons will continue to 
expect the same level of expertise and service. They would need to learn more about the subject from, for example, the texts listed in Richey's article, and more recent publications such as Limb and Volet's Bibliography of African Literatures, Parekh and Jagne's Postcolonial African Writers, and the growing number of dictionaries and encyclopedias put out by renowned publishers of reference resources. Librarians can also mine the Web for university-sponsored and enthusiasts' web sites (see Appendix) that can be bookmarked on reference desk computers.

\section{Instruction}

The move away from tool-based instruction to emphasis on critical skills and concepts that cut across individual tools is grounded in the philosophy of empowerment for users. Armed with information literacy skills, any user can search for information to meet their academic, personal, or professional needs.

One other way in which reference and instruction librarians can make African women writers more widely known is by incorporating examples from their works in instruction sessions. Typically, when literary examples are used in regular instruction classes, they tend to be from the established canons and not the emerging ones. So, for example, in teaching patrons how to search in various databases such as MLA International Bibliography, Academic Search Premier, and Humanities Abstracts, librarians may use the author Bessie Head to show users how to critically evaluate results (compare number and relevance of results), and determine which is the best source for their specific information need. Even if students had not been familiar with the author before their instruction session, the results of the various searches can help them appreciate the place of the writer in the African literary tradition.

Using the works of African women writers to teach various search concepts goes beyond teaching information literacy. It can also help foster intercultural literacy by exposing students to other literary traditions not familiar to them. Intercultural literacy would help them better understand that the human condition can be displayed in many different, cultural idioms; an understanding that could in turn prompt "research into the processes by which cultures are formed and ... [encourage] analysis of how cultures constitute themselves by reference to each other" (Miller, 1993, p. 217). As one who has taught African Literature as a general education requirement, it became abundantly clear to me that many American students had never imagined that there existed a body of literary works written by Africans until a non-western requirement came along. For those who may not have taken such a course, library instruction could perhaps plant the seed of inquiry.

\section{Research Guides}

Creating pathways to information, or tips on searching for various types of information are staples of reference librarianship. These become particularly necessary for accessing fiction whose assigned subject terms may not always reveal the themes explored in the works. An unskilled searcher looking for works that deal with the theme of education or lack of its opportunities in Africa may not be able to directly retrieve a novel or play in many of the databases currently available. This is where the mediator-librarian comes in. By collaborating with African

Studies librarians, reference librarians can create thematic guides that would group, for example, Nawal El Sadaawi's Woman at Point Zero, Tsisti Dangaremgba's Nervous Conditions, 
Ama Ata Aidoo's Changes, or Simi Bedford's Yoruba Girl Dancing. Each addresses the theme of women's educational opportunities from different yet sometimes overlapping perspectives. These works, or parts of them, could be read in a comparative education course, or in social history or sociology courses as they each present scenarios along the continuum of social change.

Having online counterparts to the print guides is one way of assuring wider knowledge of the existence of these books, and creating a potential information need. Guides, as it is widely recognized, help us "publicize and explain our collections and educate patrons" (Pankake, p. 329). But publicizing, explaining, and educating should not be limited to just faculty or students. Subject specialist librarians can also be educated and later enlisted in the bid to expand the canon and foster interdisciplinary collaboration. These guides can be made available to other librarians on campus who can then discuss new possibilities with their faculty. For example, the short stories of the Egyptian writer Alifa Rifaat that deal with the place of women in Islamic societies, or Efua Sutherland's The Marriage of Anansewa that deals with marriage agreements can be used as case studies in law classes focusing respectively on Islamic law and social contracts. Or Assia Djebar's Fantasia which is set during Algeria's war of independence in a political science course on decolonization, or Buchi Emecheta's The Joys of Motherhood in urban migration classes. Zenzele is an excellent choice for classes dealing with modern African families. It would also be interesting to have Werewere Liking's plays studied in theatre courses on the avantgarde. Additionally, other area or ethnic studies faculty may also find these guides useful for drawing inter-region parallels and contrasts. For example, Nervous Conditions and el-Sadawi's Walking Through Fire lend themselves to interesting comparative analyses with Esmeralda Santiago's When I Was Puerto Rican or Almost a Woman, or Amy Tan's The Joy Luck Club.

\section{Displays}

Traditionally, libraries have displayed their new acquisitions, or built displays around timely events and cultural themes. The list of Africa's 100 best books could be one way of bringing the public's notice to the literature from the continent. However, display boards and areas are only seen by those who physically walk into the library, and as many librarians know, only a tiny fraction of a campus' population visits the library. Consequently, the essence of the display is lost on a large proportion of the institution's community.

One strategy for reaching a wider audience is by "taking it to the streets." There is nothing to prohibit libraries from taking their displays to other parts of campus. To spark an interest in students, book jackets of the works of African women, or copies of relevant video covers can be exhibited in their Union buildings, and traditional and themed dorms to stimulate intercultural literacy and an engagement with African/international issues. Within the limits of campus posting laws, no place-elevator, bus stop, eating places-should be beyond the reach of the librarian who truly wants to market a collection (the example of the Poetry Society of America's display of poems in mass transit systems to celebrate National Poetry Month every April is worthy of emulating). It is worth remembering that the unfamiliar has a way of stimulating curiosity and ultimately, learning.

Faculty Clubs, with their tradition of inspired debates could be another venue for extralibrary displays aimed at catching the faculty's attention. Other possibilities worth exploring are department buildings. These tend to house faculty in related disciplines, so displaying "nonrelated" materials could yield interesting results. For example, by displaying book covers in nonHumanities buildings such as those housing Law, Political Science, or Agriculture departments, 
faculty could read the descriptions and make pertinent interdisciplinary connections. This in turn could lead to visits to the library to learn more, and possibly result in some kind of facultylibrarian collaboration. As Searing (1996) asserts, "Services alerting interdisciplinary scholars to a range of new information outside [sic] their core fields are more valuable than typical SDI services based on narrow interest profiles" (p. 322). Creating counterpart virtual displays and making them prominent on the library home page is another effective way of reaching many more patrons.

\section{Author Presentations}

Many speakers invited by libraries tend to be either information service providers or other librarians. In other words, speakers are chosen mostly because their message relates directly to the activities of the host library or to the library world at large. This rather insular view gives the impression that librarians, whose work takes them through a wide variety of knowledge areas, are narrowly focused on library-only issues, and are excluding the producers of that very knowledge they want their patrons to use. This anomaly can be remedied if libraries invite authors to speak to librarians. Authors discussing their works in libraries will inspire more meaningful connections between texts and librarians' use of those texts to answer reference questions. If librarians understand the various contexts in which writers create their works, they can incorporate that understanding in their baseline competencies, and impart that knowledge to patrons via reference services; this can only make for enhanced, value-added service and greater patron satisfaction.

With respect to African women writers, the majority live outside the U.S., but occasionally attend professional meetings here. To give an example, Nadine Gordimer addressed the African Literature Association (ALA) 2001 conference in Richmond, Virginia. Conferences such as this, or the African Studies Association of North America (ASA), offer opportunities for initiating contacts with them, learning about their itineraries, and perhaps inviting them to speak on campuses. Indeed, it would be much cheaper to invite them to speak on campuses while they are in the United States, and more so if the cost of bringing them to a campus can be shared with other interested departments. By hosting authors, libraries will contribute to the campus cultural calendar, and reiterate their centrality to the wider community (a fact often overlooked by many patrons).

\section{Faculty-Librarian Presentations}

Librarians can also offer workshops to faculty or hold brown bag sessions, either in the library, through Faculty Development, or other campus offices. One can envisage a session titled "African women's writing in an interdisciplinary context" based on the research guides discussed earlier in this paper. Librarians can also collaborate with teaching faculty to give joint presentations. In 2000, for example, Ohio State University's library director and a professor in East Asian Studies participated in an interdisciplinary forum titled "Old Culture/New Media." Sponsored by the College of Humanities' Institute for Collaborative Research and Public Humanities, the series, Parallel Lines, brings together "faculty engaged with similar issues . . to make presentations in an occasional brownbag lunch series" (http://www.cohums.ohio-state.edu/ HI/research.html, Jan. 29, 2003). The discussions are traditionally drawn from different disciplinary perspectives, and such an avenue is clearly one possible way of making African 
women writers more widely known and their works more accessible.

\section{CONCLUSION}

How else can librarians participate in new curricular reforms and show academic leaders across campus that they can do more than passively support new initiatives? The examples and suggestions discussed above should all form part of the communication that needs to go beyond the library's four walls. Twenty-first century librarians must position themselves more centrally in research and curricular activities on campus. By marketing their collections and expertise, and "[b]y presenting library services in a way that complements and reinforces the educational themes that campus leaders themselves are discussing and espousing, librarians can bring the library into a more central and vital position in the curriculum" (Pelster and Baker, 1992, p. 83). They must actively seek out new markets for and uses of their collections, move the boundaries that have allowed parts of library collections to be narrowly defined and used, and make the works of writers from emerging traditions more widely visible and read. Until research tools become more representative and searchers more proficient, librarians will serve as awareness agents on their individual campuses.

\section{REFERENCES}

Adams, Michael and C. Benefiel. 2000. Literary reference into the new century. In: Literature in English: A Guide for Librarians in the Digital Age.

Allan, Tuzyline. 2001. We Will Be Heard! Black Issues Book Review (March-April): 53-55.

Aderibigbe, M. R. and D. J. E. Udoh. 1990. LC subclass PL8000-8844: A case for revision. Cataloging \& Classification Quarterly 10, 3: 77-90.

Aidoo, Ama Ata. 1988. To be an African woman writer-an overview and detail. In Criticism and ideology: Second African writers' conference, edited by Kirsten Holst Petersen. Uppsala: Scandinavian Institute of African Studies.

Amaeshi, Basil. 1985. African literature as a main new class. International Library Review 17: 39-50.

Benefiel, Candace, Jeannie Miller and Diana Ramirez. 1997. Baseline competencies for the academic reference desk. Reference Services Review 25, 1: 83-93.

Berger, Iris. 1997. Contested boundaries: African Studies approaching the millennium. African Studies Review 40, 2: $1-14$.

Conteh-Morgan, Miriam. 1999. The female voice in African literature: An assessment of its impact. Unpublished Master's thesis, Kent State University.

Cullen, Charles T. 1988. Libraries and humanities: The case for scholarly activism. In Libraries and the search for academic excellence, edited by Patricia Senn Breivik and Robert Wedgeworth. Metuchen, New Jersey: Scarecrow Press.

Doherty, John J. 1998. The academic librarian and the hegemony of the canon. Journal of Academic Librarianship 24, 5: 403-406.

Gates, Henry Louis. 1990. The master's pieces: On canon formation and the African-American tradition. The South Atlantic Quarterly 89,1:89-110.

Heinzkill, Richard. 1990. The literary canon and collection building. Collection Management 13, 1-2: 51-65.

Hunter, J. Paul. 2000. The return to history in English studies. In Literature in English: a guide for librarians in the digital age, edited by Betty H. Day and William A. Wortman. Chicago: Association of College and Research Libraries.

James, Adeola (ed.). 1990. In their Own Voices: African women writers talk. London: James Curry.

Krazert, Mona and Deborah Richey. 1998. Native American Literature: Expanding the canon. Collection Building 17, 1: 4-15.

Limb, Peter and Jean-Marie Volet. 1996. Bibliography of African literatures. Lanham, MD: Scarecrow Press.

Lindfors, Bernth. 1995. Long drums and canons. Trenton, New Jersey: Africa World Press.

Malanchuk, Peter. 1990. African acquisitions: Strategies to locate and acquire current and retrospective Africana. 
Library Acquisitions 15, 4: 453-461.

Miller, Christopher. 1993. Literary Studies and African Literature: The Challenge of Intercultural Literacy. In Africa and the disciplines: The contributions of research in Africa to the social sciences and humanities, edited by Robert H. Bates, V.Y. Mudimbe, and Jean O'Barr. Chicago: University of Chicago Press.

Moore, David Chioni. 2001. Is the post- in postcolonial the post- in post-Soviet? Toward a global postcolonial change? PMLA 16, 1: 111-128.

Pankake, Marcia. 2000. Faculty liaison: Librarians and faculty as colleagues. In Literature in English: a guide for librarians in the digital age, edited by Betty H. Day and William A. Wortman. Chicago: Association of College and Research Libraries.

Parekh Pushpa and Siga Fatima Jagne. 1998. Postcolonial African writers: A bio-bibliographical critical sourcebook. Westport, Conn.: Greenwood Press.

Pelster, Natalie and Betsy Baker. 1992. Curriculum reform: Catalyst for building strong faculty/librarian partnerships. In Academic libraries: Achieving excellence in higher education, edited by Thomas Kirk. Chicago: Association of College and Research Libraries.

Quinn, Brian. 1995. Some implications of the canon debate for collection development. Collection Building 14, 1: 110.

Richey, Debora. 1995. Black African women writers: A selective guide. Collection Building 14, 1: 23-31.

Searing, Susan. 1996. Meeting the information needs of interdisciplinary scholars: Issues for administrators of large university libraries. Library Trends 45, 2: 315-342.

Szegedy-Maszak, Mihaly. 2001. Literary canons: national and international (Studies in Modern Philology 16). Budapest: Akadémiai Kiadó.

Wolke-Renk, Irmtrauad. 1984. Acquisition of African literature-Problem and challenge for book dealer and librarian. IFLA Journal 10, 4: 377-84.

\section{APPENDIX. Selected Web Sites on African Women Writers}

\section{African Women's Bibliographic Database}

http://www.africabib.org/women.html (Jan. 30, 2003)

Davis Bullwinkle's large AfricaBib database on Africa includes this database that lists over 25,000 citations to articles, conference papers, and books on women's literature. It is searchable by region/country, or subject. Display options include by title, author, or date.

\section{African Women Writers}

http://www.britishcouncil.org/virtual/africanwomen/ (Jan. 30, 2003)

This virtual publishing exhibition, mounted by the British Council for the Frankfurt International Book Fair 2000 , "celebrates the quality and diversity" of women writers from Africa. While the site only provides a synopsis of the authors' works, it is useful for its list of well-known and not so popular authors.

\section{African Writers: Voices of Change \\ http://web.uflib.ufl.edu/cm/africana/writers.htm (Jan. 30, 2003)}

Hosted by the University of Florida, the project includes pages on women writers. Information provided include bio-bibliographies, a bibliography of critical works, and links to similar web sites.

\section{Anglophone \& Lusophone African Women's Writing}

http://www.ex.ac.uk/ ajsimoes/aflit/default.htm (Jan. 30, 2003)

This site gives "detailed bibliographies, biographies of selected figures" (author's description) and points to links related to African women's writing. 
A Celebration of Women Writers

http://digital.library.upenn.edu/women/ (Jan. 30, 2003)

This is one of the better-known web projects on women writers from around the world. It brings together other web sites devoted to a writer, and allows for searching by author's name, or country of origin, time period, or ethnicity. There is, however, no separate category for African writers; some are found under the category "African-American."

Contemporary Postcolonial and Postimperial Literature in English: Postcolonial and Postimperial Authors http://www.scholars.nus.edu.sg/post/ (Jan. 30, 2003)

Part of a larger site on the culture, politics, and literary periods of former colonies, the site has a short list of African writers that includes some women. It provides biographical information on authors, a list of their published works, and student papers about the works.

\section{Gender in African and Other Postcolonial Literatures}

http://faculty.pittstate.edu/ knichols/carib.html (Jan. 30, 2003)

This directory is part of Professor Kathleen Nichols' (Pittsburgh State University, KS) postcolonial literature web project. The section on African women has links to a few authors only, but it also gives useful links on the political and cultural context of African literature.

\section{Reading Women Writers and African Literatures}

http://www.arts.uwa.edu.au/AFLIT/FEMEChomeEN.html\#english (Jan. 30, 2003)

Primarily devoted to francophone women writers, this bilingual site (in French and English) provides a useful bibliography of critical works. The works of francophone writers available in translation are also listed. Also has links to Lusophone and Anglophone women writers. 